\title{
ON NOT WANTING TO DIE: TRANSLATION AS RESURRECTION
}

\author{
Maria Freij
}

Even though Vian did not himself choose the title Je voudrais pas crever for the volume of his collected poetry - it was published posthumously in 1962 - it is a title that most fittingly captures the core premise of the book. Je voudrais pas crever (I wouldn't wanna die) encompasses, firstly, the two great contrasts in Vian's all too short existence: his passion for life and the memento mori with which he lived and which permeates this little volume of poetry. I say "little" because the book is small: the French 1972 edition contains only twenty-three poems, and in addition some writings on the Collège de 'Pataphysique, not included here. Little, also, because it appears, deceptively, to be a light read. Certainly, it is easy to be fooled by Vian's playfulness and jocularity, by his pun and word play, and by his own reiterated assertions that he is "no great poet". But Vian's work is anything but slight. The complexities at play are manifold and full of contrasts: his boyish charm, childishness and penchant for vulgarity coexist with a genuine despair and with that other side of childishness that is marked by sincerity - a way of looking at the world with awe and through the lens of a wonderful imagination.

With the notable exception of some of Vian's songs, disappointingly few of his poems have been translated into English. This is a shame, because Vian's poetry, though not easy to translate, has that special something that translates 


\section{If I Say If}

well: subject matter that, although extremely personal, survives both the passing of time and its expatriation from one linguistic home to another. It has a cheekiness that brands the poems as unmistakably "Vian" and a playfulness that invites the reader to become a co-creator, a playmate. Translating him requires the translator to engage fully in that process: co-creating, reinventing, resurrecting.

The often competing demands of, on the one hand, poetic features such as rhyme and metre, and, on the other, meaning and allusion, make translating poetry a particularly difficult and fraught task at any time. These difficulties are compounded in Vian's case by a number of other semantic and stylistic challenges: playful sonorities, onomatopoeia, pun, clever alliteration, intratextual allusions - the list is long.

To illustrate the extent of the difficulty, it is useful here to provide some examples. Vian's plays on words are arguably the most difficult but also the most enjoyable to translate (especially when combined with a rhyme scheme). In "Quand j'aurai du vent dans mon crâne" ("When the wind's blowing through my skull"), we find the phrase "ça sera une impression fosse", where the word "fausse" (false) has been replaced with the homophone "fosse" (tomb). Instead of a "false impression" we therefore have a "tomb-like impression". The translation adopted here — "gravely at a loss" — is aimed at keeping the joke while at the same time retaining the "-oss" sound. Similarly, in the same poem, the use of the terms "duchesses", "popesses", and "she-asses" is designed to respect the iconoclastic nature of the original French words ("duchesses", "papesses", and "ânesses") and the political comment implicit in them, while at the same time retaining their playful assonance. Other poems, such as "Un homme tout nu marchait" (“A stark naked man was walking”) and "J'ai mal à ma rapière" ("My rapier hurts") — or, as one could think of them, the "penis poems" - display a childish humour. In "A stark naked man was walking", the phrase "l'habit à la main" (his clothes in his hand) invites the pronunciation "la bite à la main" (dick or cock in hand) if the liaison is made. The English version proposed in this volume - "his gear in his hand" - is aimed at creating an equivalence through the (perhaps less obvious) double entendre created by the word "gear". In "My rapier hurts", Vian's nouns — "rapière", "bédane", "cardans", "graisseurs", "badiole", "sacoche” — are 


\section{If I Say If}

all inanimate objects; they are also words that could be used to describe the male anatomy. In the translation proposed here, they are rendered as "rapier", "chisel", "couplings", "lubricators", "ball-bearings" and "tool bag", respectively — words that all sustain allusions to the male genitalia and sexuality. (Some liberty has admittedly been taken in translating "ma badiole" as "ball-bearings", but the shift from a wild cherry to an object of mechanical engineering seemed warranted in terms of the unity of the imagery, and also because "badiole" conjures up "babiole" - a worthless object.) Another feature crucial to keep here was the nursery-rhyme quality of the poem, a recurring characteristic in Vian's poetry and one that often functions to soften the blow of his subtext. Naturally, the voice is lighter in the nursery rhyme and lends itself to a childlike perspective. ${ }^{1}$

In a number of the poems, rhyme serves a central purpose in establishing the poetic voice and in providing a counterweight to the darkness of the themes. In those cases, every attempt has been made to keep the rhyming structure in the translated version - a challenging task, given the syntactical differences between French and English. French, for example, favours the placement of the adjective after the noun, and to complicate matters further, Vian tends to break his lines after adjectives; however, the different syntactic patterns of French and English also open up interesting new possibilities for rhyme. In order to maintain the end-rhyme pattern, it may, for instance, be possible to change the syntax so as to draw from a different word group. This can nevertheless be a perilous exercise, as modifying the syntax can risk compromising the meaning. A good example of the necessity of this kind of change is provided by the following lines from "Ils cassent le monde" "They are breaking the world"):
Il suffit que j'aime
Une plume bleue
I need just to love
Un chemin de sable
A feather shimmering blue
Un oiseau peureux
A sandy path
A frightened bird or two

Here, "bleue" and "peureux" are both adjectives; consequently, the English version could not remain faithful to both the syntax of the original and the

\footnotetext{
1 "J'ai acheté du pain dur" ("I bought some bread, stale and all") is the most obvious example of Vian alluding to a nursery rhyme, or "comptine" — in this case "Une poule sur un mur".
} 


\section{If I Say If}

parameters of idiomatic English. Thus, instead of "a blue feather" (or "a feather blue"), we have proposed "a feather shimmering blue", and instead of simply "a frightened bird" (or "a bird frightened"), we have instead "a frightened bird or two". Some additional meaning has been introduced in both of these lines, but this was seen as less of a transgression than losing the rhyme.

Similarly, "Un poète" ("A poet") is complicated to translate due mainly to the competing demands of form and content:

Un poète

C'est un être unique

A des tas d'exemplaires

Qui ne pense qu'en vers

Et n'écrit qu'en musique

Sur des sujets divers

Des rouges ou des verts

Mais toujours magnifiques.
A poet

Is someone heaven sent

You can meet any time

Who thinks only in rhyme

Writes with musical bent

On most any paradigm

Be it crude or sublime

But always magnificent.

While the rhyme-scheme here (ABCCBCCB) has been kept, some modifications had to be made to the content. The "unique being" of line 2, for example, becomes "someone heaven sent", with the result that the oxymoron in lines 2-3 (a unique being of which there are many to be found) is less obvious in the English version. The translation of the line "Des rouges ou des verts" is also difficult, given that "verts" (green) is a homophone of "vers" (verse, poetry). The word "vert" in French can also mean "crude" or "saucy". The proposed translation, while no doubt less rich in allusion than the original, represents at least an attempt to maintain the contrast created by the opposing colours (red and green) while at the same time maintaining the rhyme and capturing at least one of the possible meanings of "vert".

Vian often changes the pronunciation of words in order to create the desired metre or rhyme. In "Je n'ai plus très envie" ("I'm no longer at ease"), for example, the adjective "paresseux" ("lazy") becomes "parressieux" so as to rhyme with "vieux" ("old"), "sérieux" ("serious") and "consciencieux" ("conscientious") in the three preceding lines. In keeping with that spirit, the translated version proposed here takes similar licence in order to reproduce a comparable rhyme pattern, through the combination of real and modified or invented words: "senescentious", "serious", "conscientious" and "indolentious". 


\section{If I Say If}

There are, of course, occasions on which the decision has been made that a rhyming translation would mean too significant a corruption of the content. In such cases, an attempt has been made to compensate for this loss through the use, for example, of consonance. To take one example, in "Il y a du soleil dans la rue" ("There is sunshine in the street"), there is a couplet that includes three rhyming words: "sèche" ("dry"), "rêche" ("harsh") and "fraîche" ("cool", "fresh"). These words have been translated as "awash", "harsh" and "fresh", respectively. Here, the consonance atones to a degree for the lack of rhyme, and these words importantly also keep the onomatopoeia and evoke the sound of running water. (It should be noted that "dry", the most obvious translation of the French term "sèche", is shifted to the second part of that particular line of verse, thereby offering further lexical compensation.)

Metre is also important in most of Vian's poems - he was, after all, a musician - and every attempt has been made either to retain the original cadence or to create a comparable one in the translation. The rhythms of English and French are different, and it is not always possible to keep the same syllable count in translation. The aim, though, has been to stay as close as possible to the original, both in terms of scansion and visual presentation, and as few syllables as possible have been added or taken away. This sometimes requires making adjustments, particularly where rhyme is also a feature. This is illustrated by the following lines from "I wouldn't wanna die":

La terre qui craquelle

Lodeur des conifères

Et les baisers de celle

Que ceci que cela

La belle que voilà
The crunch of the soil

The smell of the pine

And the kisses so fine

Of what's her name - ah!

This beauty — voilà

The rhymes have been maintained here, although their position has shifted slightly, and the six-syllable lines of the original have become five-syllable lines in English (with the exception of the middle line). But overall, the regularity of the metre and the rhymes remain strong features of the translated version.

While we have focused here on rhyme and metre, there are other recurring features that pose problems for the translator. Many factors come into play in Vian's technique, and most of them result from his creative use 


\section{If I Say If}

of language. His word play, in particular, is as intelligent as it is frequent. In addition to the use of homophones, which has been discussed above, there are numerous uses of alliteration, repetition and, of course, pun. Sometimes Vian's word play works on several levels, such as in "Donnez le si" ("If I say if"), one of the most multi-layered and complicated poems in the collection, in which Vian plays with the fact that some French words are pronounced like English words and, conversely, some English words can be found in French, with or without the same meaning. The "si" of the French title corresponds to the English "ti" in the musical scale but is also the French word for "if", which features in the following line. However, the French word "if" means a "yew" - which throws to the word "tri" in the next line ("le tri" in French actually means "selection" or "sorting"). And so it continues. Vian engages in bilingual humour, here, while maintaining the inter- and intratextuality at which he excels. The subtext nevertheless remains dark, as the card game of bridge reveals itself to be a metaphor for duplicity.

Two poems introduce a very specific set of complications. In "Si les poètes étaient moins bêtes" ("If poets weren't such fools"), Vian invents a whole range of words, some of which are based, more or less loosely, on actual words. In one section, he announces that he is introducing a list of fishes, but the ensuing list contains a number of invented words:

Il y aurait deux cents poissons

Depuis le croûsque au ramusson

De la libelle au pépamule

De l'orphie au rara curule

Et de l'avoile au canisson
There would be two hundred fishes

From crustoceans to antlishes

From lampdragoons to pepaflies

From needlefish to rare curuleyes

And from bowsprats to poodlefishes

Some of these words are more or less identifiable. The "orphie" of the third line is the French term for a garfish or needlefish. The "libelle" ("lampoon") of the third line becomes "libellule" ("dragonfly") if we add the final syllable of the following word to it. In similar fashion, the words "avoile" and "canisson" from the fourth line become "avoine" ("oats") and "calisson" (a type of sweet made from ground almonds) if we swap two of their consonants around. But of course, "l'avoile" can also be read as "la voile" ("the sail") and "canisson" is not too distant from "caniche" ("poodle"). It is clearly not possible in translation to capture all of the possible allusions and lexical connections that are present 


\section{If I Say If}

in the original French, but the version proposed here aims at least to convey something of that inventive word play.

We similarly find invented words in "Un jour" ("One day"). The term "volutin", for instance, evokes both "volute" ("spiral") and "lutin" ("elf”) - hence "spirelf" in our translation. The word "ivrunini" is reminiscent of "ivrogne", or "drunkard", whereas "analognes" is close to "analogues" or "analogies". The solutions proposed here — "drunkaninny" and "anahologies" - hopefully respect the inventiveness and spirit of the original text.

Trying to decipher Vian's language and solve mysteries such as these involves trying to unearth original meanings, including what two (sometimes invented) words he has used to make a third. This is forensic work that requires some lateral thinking as well as the close examination of meaning, imagery and linguistics. But unlike the forensic scientist, whose task it is to determine the cause of death, the translator is aiming to resurrect the text. In that sense, it is highly desirable for the translated texts to stand alone and be judged in their own right. Nevertheless, it may be useful for readers to have at their disposal some commentary that explains this behind-the-scenes work. That is the function of the notes that are provided on the various poems at the end of this volume. Here, specific points of interest may be clarified or given their due attention: intertextual nods may be acknowledged, puns highlighted and cultural specificities clarified. If a translator's commentary cannot be as specific as to explain all individual choices, it can at least introduce the reader to the grid of ideas that have been applied during the translation process and provide a sense of the philosophy that has guided the translator.

For monolingual and bilingual readers alike, translation offers new ways of approaching a text. More than this, though, what translation ultimately does is allow the text to keep being recreated - it gives it new life. It is, in other words, a sort of resurrection of a text into a different linguistic, cultural and temporal context. And a text that is read, recreated and read again is saved from the oblivion that Vian, in his title poem, wanted so much to avoid. 